\title{
SYNTHESIS, SPECTROSCOPIC AND THERMOGRAVIMETRIC STUDIES ON SOME TRANSITION METAL COMPLEXES WITH HYDRAZONE LIGANDS.
}

\author{
Ahmed A. Shabana ${ }^{1}$, Hamdy A. Hammad ${ }^{1}$, Hassan A.Sadek ${ }^{1, a}$, NAA Ghany ${ }^{2}$ \\ Saleh D. Mekkey ${ }^{1}$, Osama M. Yassin ${ }^{3}$. \\ ${ }^{1}$ Chemistry Department,Faculty of Science,Azhar University,Naser city,11884,Cairo ,Egypt . \\ Hassanelfarsy@yahoo.com. \\ ${ }^{2}$ Physical chemistry, National Research centre, Dokki, 12622, Giza, Egypt. \\ Na_manakhly@yahoo.com \\ ${ }^{3}$ Physics Department, Faculty of Science, Azhar University, Naser city, 11884, Cairo, Egypt. \\ Om_yassin_2030@yahoo.com
}

\begin{abstract}
Complexes of $\mathrm{Cu}$ (II) and $\mathrm{Ni}$ (II) derived from 2-amino- $\mathrm{N}^{\prime}$-(2-hydroxybenzylidene) benzohydrazide(ASH), 2-amino- $\mathrm{N}^{\prime}$ benzylidenebenzohydrazide(ABH), N'-(3-phenylallylidene)-2-((3-phenylallylidene)amino)benzohydrazide(ACH), and N'-(4methoxybenzylidene)-2-((4-methoxybenzylidene)amino)benzohydrazide(AAH)have been synthesized and characterized by elemental and thermal analysis(TGA), IR, U.V-Visible, ${ }^{1} \mathrm{H}$ NMR (Ligands) spectral studies, magnetic susceptibility, atomic absorption and molar conductivity measurements, the ligand (ASH) act as tridentate with ONO donor sites, the bonding sites are carbonyl oxygen, azomethine nitrogen and phenolate oxygen, the other ligands act as bidentate with ON donor sites, the bonding sites are carbonyl oxygen, azomethine nitrogen, the metal complexes exhibit different geometrical structures such as square pyramidal,tetrahedral, square planar and octahedral. The Coats-Redfern equation has been used to calculate the thermodynamic parameters for different thermal decomposition steps of some complexes.
\end{abstract}

KEWORDS: hydrazone, transition metal complexes, coats-redfern equation, Gaussiananalysis



\section{Council for Innovative Research}

Peer Review Research Publishing System

Journal: Journal of Advances in Chemistry

Vol. 12 , No. 3

editor@cirjac.com

www.cirjac.com 


\section{INTRODUCTION}

In recent years the chemistry of hydrazone has been extensively studied, owing to their coordinating capability, pharmacological activity and biological properties. The complexes of transition metals with hydrazone ligands have shown wide interest of biological and pharmaceutical activities such as antimicrobial, antibacterial, antifungal, anti-inflammatory, anticonvulsant,antibercular,antiviral, antioxidant and inhibition of tumor growth[1]-[4].The tridentate of benzhydrazone derivative ligands containing ONO donor atoms can be synthesized with any aldehyde or ketone. The presence of donor atoms in the ligands plays an important role in the formation of a stable chelate ring and this situation facilitates the complexation process[5]. The bioinorganic chemistry focused agreat attention to hydrazone complexes because many of these complexes have biologically important species[6]. In analytical chemistry hydrazone find application by act as multidentate ligands[7] with metal (usually transition metal group). Various studies have also shown that tha azomethine group having a lone pair of electrons in either a $\mathrm{p}$ or $\mathrm{sp}^{2}$ hybridized orbital on trigonallyhybridized nitrogen has considerable biological importance. The hydrazone schiff's base show clearly keto-enol tautomerism and can link metal ion in neutral medium in medicinal application[8]. Thus, we are motivated to undertake a systematic study of preparation and characterization of transition metal complexes of $\mathrm{Cu}$ (II) and $\mathrm{Ni}$ (II) metal ions with some aroylhdrazone.

\section{EXPERIMENTAL}

\subsection{Chemicals and instruments}

Aldehydes were obtained from Biotech for laboratory chemicals, DMSO from Merk and all other chemicals used in the study were of reagent grade and applied without further purification. The elemental analysis were performed using CHNS932 (LECO) Vario Elemental Analyzers, the molar conductance of complexes were measured using conductance/TDS 72 instrument. Infrared spectra were recorded on PerkinElmer FT-IR 200 spectrometer thermoelectron in $4000-400 \mathrm{~cm}$ ${ }^{1}$ region as $\mathrm{KBr}$ pellets. The UV-Vis spectra were measured in the range of $200-800 \mathrm{~nm}$ using Perkin-Elemer Lambda 35 UV-Vis. The magnetic measurements were carried out using gouy method. The ${ }^{1} \mathrm{H}$ NMR spectra were recorded in DMSO and $\mathrm{D}_{2} \mathrm{O}$ usingGEMINI-200 NMR spectrometer. The melting point of was measured using electro thermal melting point SMPI apparatus. TGA analysis was recorded on TGA-50H in range of $25-1000 \mathrm{C}^{\circ}$.

\subsection{Synthesis of ligands}

A mixture of 2 -aminobenzohydrazide $(0.01 \mathrm{~mol})$ and substituted aromatic aldehydes $(0.01$ molsalicylaldhyde, $0.01 \mathrm{~mol}$ benzaldhyde, $0.02 \mathrm{~mol}$ cinnmaldhyde, $0.02 \mathrm{~mol} 4$ - anisaldhyde) in absolute ethanol ( $25 \mathrm{ml})$ was heated under reflux for $1 \mathrm{hr}$. this mixture was allowed tocool and the solid product was collected and recrystallized from ethanol[9], [10]. Structures are shown in(Fig.1)

\subsection{Synthesis of metal complexes}

The complexes were prepared by the reaction $\mathrm{Cu}$ (II) acetate and $\mathrm{Ni}$ (II) acetate with $\mathrm{ASH}, \mathrm{ABH}$.Ligands in molar ratio $(1: 1)$ and with $\mathrm{ACH}$ and $\mathrm{AAH}$ ligands in molar ratio (1:2). The mixture was heated and reflux for 3hr with stirring. the product was filtered off, washed several times with ethanol and dried over anhydrous $\mathrm{CaCl}_{2}$ in desiccator.[11]

\subsection{Determination of metal content in complexes.}

Metal complexes $(5 \mathrm{mg}$ ) were weighted and then concentrated nitric acid (10 ml) was added. The solution was heated unti few drops of the solution were remained. $10 \mathrm{ml}$ deionized water was added to this hot solution, repeating this step five times then transferred the solution to a $100 \mathrm{ml}$ volumetric flask. It was made up to the mark using deionized water and then the amount of metal was estimated by Atomic absorption spectroscopy.

\section{RESULTS AND DISCUSSION}

The analytical data for ligands and its complexes are given in table 1. The elemental analysis reveal that 1:1 (ligand: metal) stoichiometry for ligands $\mathrm{ASH}$ and $\mathrm{ABH}$ and 2:1 (ligand: metal) for ligands $\mathrm{ACH}$ and $\mathrm{AAH}$. The isolated complexes are insoluble in most organic solvents but are soluble in hot DMSO.

\subsection{IR spectral studies}

The infrared spectra of ligands and related complexes were recorded to confirm their structures. The vibrational frequencies and their tentative assignments are listed in (Table 2). The hydrazone ligands can exist in the keto or enol forms or an equilibrium mixture of two forms since it has an amide group $-\mathrm{NH}-\mathrm{C}=\mathrm{O}$ [12] , However the IR data indicates that in solid state the ligands is in keto-form. The IR spectrum of ASH ligand reveals a broad band at $3411 \mathrm{~cm}^{-1}$ attributed tov $(\mathrm{OH})$ phenolic. The bands at $3322-3267 \mathrm{~cm}^{-1}$ due to $v\left(\mathrm{NH}_{2}+\mathrm{NH}\right)$, the strong band with a shoulder noticed at 1653 $\mathrm{cm}^{-1}$ can be attributed to $v(\mathrm{C}=\mathrm{O})$ [13], the spectrum also shows bands at $1600 \mathrm{~cm}^{-1} \delta(\mathrm{N}-\mathrm{H}), 1528 \mathrm{~cm}^{-1} v(\mathrm{C}=\mathrm{N}), 874 \mathrm{~cm}$ ${ }^{1} v(\mathrm{~N}-\mathrm{N})$. The IR spectra of complexes corresponding to ASH ligands reveal absence of $\mathrm{OH}$ band indicatingdeprotonation of the phenolic oxygen and subsequent coordination to the metal ion. This is further supported by upward shifting of $v(\mathrm{C}-$ O) band by $14-41 \mathrm{~cm}^{-1}$ confirming the coordinating of phenolic oxygen to the metal ion[14].The disappearance of $v(\mathrm{C}=\mathrm{O}), v$ $(\mathrm{N}-\mathrm{H})$ bands in complexes, suggests enolization of carbonyl oxygen and this is supported by appearance of 



Fig 1: structures of ligands

New bands at $(1369-1365) \mathrm{cm}^{-1}$ and $(540-542) \mathrm{cm}^{-1}$ attributed to $v(\mathrm{C}-\mathrm{O})$ enolic and $v(\mathrm{M}-\mathrm{O})$ respectively, suggests the coordination of carbonyl oxygen to the metal ion after deprotonating. The band ofv $(\mathrm{C}=\mathrm{N})$ in ligand is found to be shifted to lower frequency by $19-28 \mathrm{~cm}^{-1}$ indicating the coordination via the Azomethine nitrogen [15], which also is confirmed by appearance of bands in the range of $437-443 \mathrm{~cm}^{-1}$ which have been assigned to $v(\mathrm{M}-\mathrm{N})$. The $(\mathrm{N}-\mathrm{N})$ band in ligand is shifted to higher frequency in complexes at $890-896 \mathrm{~cm}^{-1}$ and this frequency shift supported the coordination through azomethine nitrogen[16]. The complexes also show newbands at 3380 and $3426 \mathrm{~cm}^{-1}$ attributed to the presence of water molecules. The IR spectrum of $\mathrm{ABH}$ ligand indicates the observation of $v\left(\mathrm{NH}_{2}\right)$ vibrations as doublet at $3488-3376 \mathrm{~cm}^{-1}$, the $v(\mathrm{~N}-\mathrm{H})$ band of hydrazine moiety appears at $3210 \mathrm{~cm}^{-1}$, the band observed at $1634 \mathrm{~cm}^{-1}$ is assigned to carbonyl group, the bands at 1541 and $1250 \mathrm{~cm}^{-1}$ is attributed to $(\nu \mathrm{C}=\mathrm{N}, \delta \mathrm{N}-\mathrm{H})$ and amide III respectively. By comparing the IR spectra of complexes with that of $\mathrm{ABH}$ ligand, it can be deduced that enolization of carbonyl oxygen and subsequent coordination to the metal ion through the oxygen after deprotonation , this is supported by disappearance of $v(\mathrm{~N}-\mathrm{H})$ band of hydrazinemoiety and appearance a new bands at $(1367-1365) \mathrm{cm}^{-1}$ and $(597-620) \mathrm{cm}^{-1}$ due to $v(C-O)$ enolic and $v$ $(\mathrm{M}-\mathrm{O})$ respectively, and also the band of azomethine group in free ligand is shifted to lower frequency by $29-35 \mathrm{~cm}^{-1}$, the band in free ligand at $967 \mathrm{~cm}^{-1}$ is shifted to higher frequency in complexes at 1034 and $1018 \mathrm{~cm}^{-1}$ due to $v(\mathrm{~N}-\mathrm{N})$ suggesting the coordination through azomethine nitrogen and is supported by appearance of new band at ( $452-432$ ) $\mathrm{cm}$ ${ }^{1}$ due to $v(\mathrm{M}-\mathrm{N})$. The observed New bands in range of $1590-1598 \mathrm{~cm}^{-1}$ and $1445-1446 \mathrm{~cm}^{-1}$ range are assigned to $v_{\text {as }}$ and $\mathrm{v}_{\mathrm{s}}\left(\mathrm{COO}^{-}\right)$referring to the coordinating acetate, which coordinate as bidentate ligand. The IR spectraof $\mathrm{ACH}$ ligand showed bands at 3256, 1628, 1515, 1395 and $967 \mathrm{~cm}^{-1}$ assigned to $v(\mathrm{~N}-\mathrm{H}), v(\mathrm{C}=\mathrm{O}),(v \mathrm{C}=\mathrm{N}+\delta \mathrm{N}-\mathrm{H})$, amide III and $v(\mathrm{~N}-$ $\mathrm{N})$ respectively. The IR spectra of the complexes of $\mathrm{ACH}$ ligands show carbonyl group shifted to lower frequency by $22-26$ $\mathrm{cm}^{-1}$ suggesting that ligand attached to metal through carbonyl group and this is further supported by the appearance of new band in the range of $421-447 \mathrm{~cm}^{-1}$ due to $(M-O)$, also the lower shift of $v(C=N)$ band suggested that the azomethine nitrogen acts as donor site, this is further supported by shifting of $v(\mathrm{~N}-\mathrm{N})$ band to higher frequency and appearance of new band due to $v(\mathrm{M}-\mathrm{N})$ at 519 and $521 \mathrm{~cm}^{-1}$, also the bands at $(1500,1501) \mathrm{cm}^{-1}$ and $(1444,1442) \mathrm{cm}^{-1}$ may be due to $v_{\text {as }}$ and $\mathrm{v}_{\mathrm{s}}\left(\mathrm{COO}^{-}\right)$, The new bands observed at 3404 and $3438 \mathrm{~cm}^{-1}$ are assigned to water molecules. The most significant IR bands of AAH ligand are observed at 3338, 1626, 1522, 1357, 1247 and $902 \mathrm{~cm}^{-1}$ assigned to $v(\mathrm{~N}-\mathrm{H}), v$ $(\mathrm{C}=\mathrm{O}), v(\mathrm{C}=\mathrm{N})+\delta(\mathrm{N}-\mathrm{H}), v(\mathrm{C}-\mathrm{O}-\mathrm{C})$, amide III and $v(\mathrm{~N}-\mathrm{N})$ respectively. The IR spectra of complexes show that the carbonyl band is shifted to lower frequency by comparing with that of ligand, the shift indicates coordination of carbonyl oxygen to metal ion and also supported by appearance of new bands at 447 and $485 \mathrm{~cm}^{-1}$ due to $v$ (M-O). The stretching frequency of $v(C=N)$ shifted to lower frequency at 1500 and $1507 \mathrm{~cm}^{-1}$ and $v(N-N)$ is shifted to higher frequency at 919 and $904 \mathrm{~cm}^{-1}$, thereby suggests participation of azomethine nitrogen, the bands at 1500-1507 and $1445-1436 \mathrm{~cm}^{-1}$ is attributed to $v_{\mathrm{as}}$ and $\mathrm{v}_{\mathrm{s}}\left(\mathrm{COO}^{-}\right)$, and also band at $3444-3430 \mathrm{~cm}^{-1}$ is assigned to water molecules.

\section{2. ${ }^{1} \mathrm{H}$ NMR spectroscopy}

The assignment of the main signals in the ${ }^{1} \mathrm{H}$ NMR spectra of the ligands are given in (table 3 ), ${ }^{1} \mathrm{H}$ NMR spectra of ligands exhibited multiple signals of the aromatic protons in the range of $6.5-8.5 \mathrm{ppm}$, the $\delta \mathrm{N}-\mathrm{H}$ proton appears in $\mathrm{ASH}, \mathrm{ABH}$, $\mathrm{ACH}$ and $\mathrm{AAH}$ at $11.449,11.527,7.481$ and $7.625 \mathrm{ppm}$ respectively, the spectrum of $\mathrm{ASH}(\mathrm{Fig} 2)$ exhibits a signal at $\delta$ 11.849 assigned to $\mathrm{OH}$ proton, the signal at 6.441 and $6.309 \mathrm{ppm}$ in the spectrum of $\mathrm{ASH}$ and $\mathrm{ABH}$ is assigned to $\mathrm{NH}_{2}$

proton respectively, the disappearance of $\mathrm{OH}, \mathrm{NH}, \mathrm{NH}_{2}$ protons is confirmed after the addition of $\mathrm{D}_{2} \mathrm{O}$. The $(\mathrm{CH}=\mathrm{N})$ proton appears as singlet at $8.568,8.391,8.749 \mathrm{ppm}$ in $\mathrm{ASH}, \mathrm{ABH}$ and $\mathrm{AAH}$ respectively while the $(\mathrm{CH}=\mathrm{N})$ proton in $\mathrm{ACH}$ ligand appears as a doublet at $8.7 \mathrm{ppm}$.

\subsection{Conductivity measurement}

The molar conductance $\Lambda_{\mathrm{M}}$ values of metal complexes in DMSO $\left(10^{-3} \mathrm{M}\right.$ solution) were measured at room temperature and the results are listed in (table 4).it is concluded from the results that metal complexes 1, 2, 3 and $\mathbf{4}$ were found to have molar conductance values in range of $10-35 \Omega^{-1} \mathrm{~cm}^{2} \mathrm{~mol}^{-1}$ indicating that they are not electrolytic in nature and there is no counter ion present outside their coordination sphere[17].On the other hand, the molar conductivity values of 
complexes 5-8 were found to have molar conductance values in the range of $99-145 \Omega^{-1} \mathrm{~cm}^{2}$ mol ${ }^{-1}$ indicating the ionic properties of these complexes.

\subsection{Electronic spectra and magnetic susceptibility}

The assignment of the observed electronic absorption bands of the transition metalcomplexes as well as the geometry and magnetic data of the complexes are shown in (Table 4). The ligands have spectral bands in the range of 39,682-27,100 $\mathrm{cm}^{-1}$ corresponding to $\pi \pi^{*}$ andn $\longrightarrow \pi^{*}$ transition DMSO solvent.

In ASH complexes: the electronic spectrum of $\mathrm{Cu}$ complexshows abroad band at $15432 \mathrm{~cm}^{-1}$ corresponding to $\mathrm{d}-\mathrm{d}$ transition characteristic of square pyramidal distorted structure of $\mathrm{Cu}$ (II) complex[18], [19], this band has been resolved to combination of four Gaussian functions(Fig 3a). According to previousreported experimental and theoretical data of Cu (II) compounds, the Gaussian function expected for square pyramidal structure, would be three peaks corresponding tod $z^{2} d_{x}^{2}{ }^{2}, d_{x y} d_{x}^{2} \frac{2}{2} d_{x z}, d_{y z} d_{x}^{2}-y^{2}$ transitions[20]. The four Gaussian functions are attributed to the low symmetry around of $\mathrm{Cu}$ (II), four oxygen and one nitrogenatoms. In addition to the nitrogen apical atom shows a deviation of its perpendicularity to the square pyramidal base whichestablishes an interaction between electronic density of the nitrogen ligand and some of the atomic orbitals $d_{x z}$ and $d_{y z}$, promoting a minimum differentiation between both $d$ atomic orbitals (fig 3b).the magnetic moment $\mu_{\text {eff }}=2.02$ B.M. which confirms the square pyramidal structure[21]. The electronic spectrum of $\mathrm{Ni}$ (II) complex (2) shows two absorption bands at 24390 and $18762 \mathrm{~cm}^{-1}$ characteristic of high spin five coordinated Ni (II) complex and could be assigned to ${ }^{3} \mathrm{~B}_{1 g}{ }^{3} \mathrm{~A}_{2 g}(p)$ and ${ }^{3} \mathrm{~B}_{1} \mathrm{E}_{g}(p)$ respective of square pyramidal environment with $\mathrm{D}_{4 h}$ symmetry [22], the magnetic moment $\mu_{\mathrm{eff}}=2.86$ B.M.is consistent with square pyramidal geometry.

In ABH complexes: The copper (II) complex shows a band at $17544 \mathrm{~cm}^{-1}$ which corresponding to the transition of the ${ }^{2} T_{2}^{2} E_{2}$ consistent with distorted tetrahedral geometry[23], this is supported by magnetic moment $\mu_{\text {eff }}=1.83$ B.M. The magnetic moment value of $\mathrm{Ni}$ (II) complex is 3.36 B.M., suggesting the presence of two unpaired electrons that reveals the spin free nature of the complex corresponding to tetrahedral geometry. The nickel complex shows bands at 19493 and $27624 \mathrm{~cm}^{-1}$ due to ${ }^{3} \mathrm{~T}_{1 \mathrm{~g}}(\mathrm{~F})^{3} \mathrm{~T}_{1}(\mathrm{P})$ and ${ }^{3} \mathrm{~T}_{1}(\mathrm{~F})^{3} \mathrm{~A}_{2}(\mathrm{~F})$ tronsition indicating tetrahedral geometry[24].

In ACH and AAH complexes: The electronic spectra of the copper (II) complexes showed d-d broad bands at 15873 and $16528 \mathrm{~cm}^{-1}$ respectively which can be assigned to ${ }^{2} \mathrm{E}_{\mathrm{g}}{ }^{2} \mathrm{~T}_{2 \mathrm{t}}$ tansitionof an octahedral geometry. Though, in cases where the ${ }^{2} E_{g}$ and ${ }^{2} T_{2 g}$ states of the octahedral $\mathrm{Cu}$ (II) ion $\left(\mathrm{d}^{9}\right)$ split under the influence of the tetragonal distortion, three transitions ${ }^{2} \mathrm{~B}_{1 \mathrm{~g}}{ }^{2} \mathrm{E}_{g}{ }^{2} \mathrm{~B}_{1 \mathrm{~g}}{ }^{2} \mathrm{~B}_{2 \mathrm{~g}}$, ${ }^{2} \mathrm{~B}_{1 \mathrm{~g}}{ }^{2} \mathrm{~A}_{1 \mathrm{~g}}$ are exped their very close energies could have made them appear in the form of one broad band envelope. Our results are in good agreement with those reported for a distorted octahedral geometry around $\mathrm{Cu}$ (II) ion[25]. The magnetic moment values (1.62 and 1.71 B.M. respectively) are in agreement with an octahedral geometry. The electronic spectra of $\mathrm{Ni}$ (II) complexesdisplay only two bands at (16234 - 24390) and (14265 16447) $\mathrm{cm}^{-1}$, which are attributed to ${ }^{3} \mathrm{~A}_{2 g}(F)^{3} \mathrm{~T}_{1 \mathrm{~g}}(F) \quad\left(v_{2}\right)$ and ${ }^{3} \mathrm{~A}_{2 \mathrm{~g}}\left(F_{3}\right)^{3} \mathrm{~T}_{1 \mathrm{~g}}(p)\left(v_{3}\right)$ transitions, octahedral nickel(II) complex. The values of magnetic moment for nickel(II) complexes are 2.80 and 2.87 respectively which is consistent with two unpaired electrons state confirming octahedral geometry for nickel(II)[26], [27].
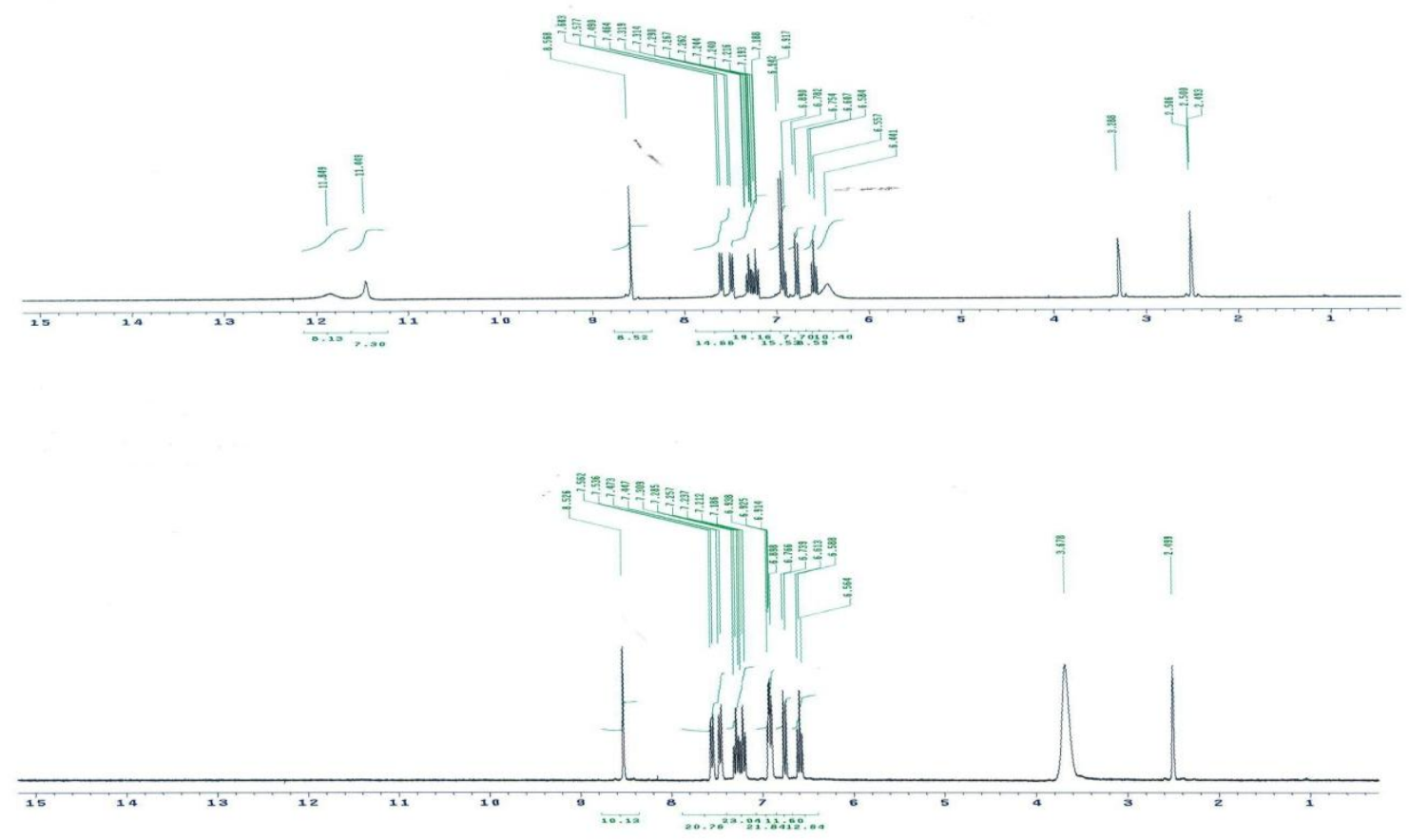
Fig 2: ${ }^{1} \mathrm{H}$ NMR spectra in DMSO-d 6 solvent of the (a) ASH ligand and (b) ASH ligand after the addition of $\mathrm{D}_{2} \mathrm{O}$

\subsection{Thermogravimetric analyses}

The thermogravimetric of complexes were recorded in the temperature range $25-1000 \mathrm{C}^{\circ}$ (Fig 4). Thethermogravimetric data are given in (table 5). The thermal decomposition process of complex 1involves three decomposition steps; the first step in the decomposition is started at 99-220 $\mathrm{C}^{\circ}$ corresponding to loss of two coordinated water molecules (weight loss; calc./found\%; 5.37/5.89), the second step in the range 221-338C corresponding to loss of species molecules( $2 \mathrm{HCN}$ and $2 \mathrm{CN}$ ) with weight loss (calc./found\%;15.80/15.10), while the third step in range 338-529 $\mathrm{C}$ which is attributed to the loss of fragment $\left(\mathrm{C}_{24} \mathrm{H}_{20} \mathrm{~N}_{2} \mathrm{O}_{2}\right)$ with weight loss (calc./found; 54.90/54.42) leaving cupper oxides $2 \mathrm{CuO}$ as final residue (calc/found; 23.74/24.59). The TG curve of the complex2 reveals that the decomposition takes place in two steps. The first one at $74-163 \mathrm{C}^{\circ}$ corresponds to a weight loss of (calc/found\%; $5.44 / 4.76 \%$ ) and is probably due to decomposition of the twocoordinated water, the second stage of decomposition takes place at $236-571.2 \mathrm{C}^{\circ}$ Corresponding to the organic moiety of complex with weight loss (calc. /found\%; 76.76/76.56) leavening the nickel metal 2 Ni as final residue (calc./found\%;17.79/17.73). The thermogravimetric analysis of complex 3 reveals two steps of decomposition, the first step started in range of 211-236 $\mathrm{C}^{\circ}$ corresponding to fragments (acetate group, $\mathrm{N}_{2}, \mathrm{HCN}$ and phenyl ring) with weight loss (calc. /found \%; 52.98/52.24), the second step takes place at 292-336 C which is attributed to propane species (weight loss; calc. /found \%;11.64/12.88), the residue of decomposition is $\mathbf{C u O}+\mathbf{4 C}(\mathrm{Calc} / \mathrm{found} \%$; $35.33 / 34.88)$. thedecomposition of complex 4 shows two stages, the first step in the range of $183-353 \mathrm{C}^{\circ}$ and is attributed to elimination of $\mathrm{CH}_{3} \mathrm{COO}^{-}, 2 \mathrm{C}_{2} \mathrm{H}_{2}$ and $\mathrm{CN}$ with weight loss (calc. / found\%; 38.5/37.62\%), the second step started at $353 \mathrm{C}^{\circ}$ and ended at $449 \mathrm{C}$ indicating loss of benzene ring and $2 \mathrm{HCN}$ with weight loss (calc. /found\%; 38.2/39.3\%), the final residue is found to be $\mathbf{N i O}+\mathbf{4 C}$ (calc. /found; $24.40 / 23.08$ ). the TGA curve of complex $\mathbf{5}$ isindicating four steps. The temperature range $42-183 \mathrm{C}$ corresponding to the loss of lattice water, two acetate group, $\mathrm{CO}$

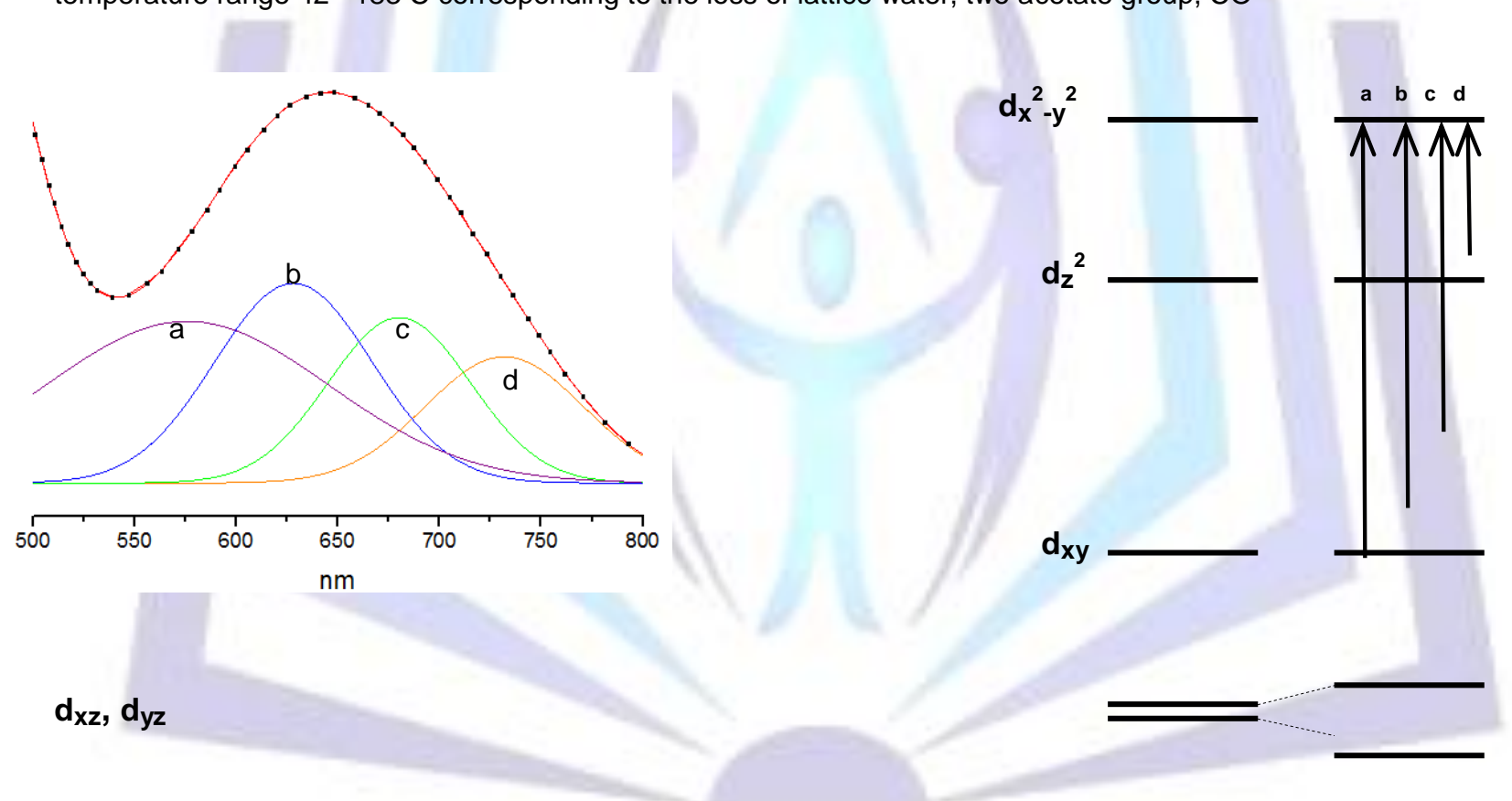

(a)

(b)

Figure 3: (a) Electronic spectrum in visible region of complex 1. Experimental ( .... ), adjusted by Gaussian curves and their sum (- ), (b) proposed d-d transition in low symmetry atomic d orbitals.

and NH fragments (calc. /found; 17.99/18.10). The second step (183-237C ) indicates the loss of two coordinated water, $5 \mathrm{HCN}$ and $3 \mathrm{C}_{2} \mathrm{H}_{2}$ (calc. /found; $25.04 / 25.53 \%$ ), the third peak appeared in the range $237-317 \mathrm{C}$ is assigned to elimination of $2 \mathrm{C}_{2} \mathrm{H}_{2}$, phenyl ring and $\mathrm{C}_{6} \mathrm{H}_{4}$ with weight loss (calc. /found \%; 20.61/19.15\%). The last step refers to loss of $\mathrm{C}_{2} \mathrm{H}_{2}$ and 3 phenyl ring groups (calc. /found; 25.8/26.6) leaving $\mathbf{C u O}+\mathbf{2 C}$ (calc. /found; 10.41/10.65). the complex 6 shows three stages, the first stage in the range of $30-119 \mathrm{C}^{\circ}$ and is assigned to loss of 3 lattice water molecules (calc. /found;5.26/5.73\%), the second step $\left(120-303 \mathrm{C}^{\circ}\right)$ indicates elimination of two coordinated water and two acetate groups (calc. /found;15.01/14.37). the final step in rang of $307-374 \mathrm{C}^{\circ}$ referring to weight loss of $67.10 \%$ (calc. $66.59 \%$ ) which is due to the organic part of complex leaving $\mathbf{N i O}+\mathbf{5 C}$ as residual form (calc./found\%; $13.13 / 12.89 \%$ ). The TGA studies of the complex 7 involve two steps, the first step in range of $\left(170-383 \mathrm{C}^{\circ}\right)$ corresponding to loss of two coordinated water, two acetate group, $\mathrm{CO}, 2 \mathrm{C}_{6} \mathrm{H}_{4}$ and $2 \mathrm{C}_{7} \mathrm{H}_{7} \mathrm{O}$ with weight loss (calc./found\%;55.50/55.70\%), the second step at $295-456 \mathrm{C}^{\circ}$ 
involves loss of $2 \mathrm{HCN}, 2 \mathrm{NH}$ and $\mathrm{C}_{8} \mathrm{H}_{8} \mathrm{ON}_{2}$ (calc./found\%;35.64/35.53\%) and the final residue is attributed to $\mathrm{NiO}+\mathrm{C}$ (calc. /found\%;8.76/8.77\%).

\subsubsection{Calculation of thermodynamic parameter of complexes}

the thermodynamicparameter for thermal decomposition steps of complexes have been studied employing the CoatsRedfern equation in the following form [28].

$\log \left[\frac{1-(1-\alpha)^{1-n}}{T^{2}(1-n)}\right]=\log \frac{A R}{\Theta E^{*}}\left[1-\frac{2 R T}{E^{*}}\right]-\frac{E^{*}}{2.303 R T} n \neq 1(1)$

$\log \left[\frac{-\log (1-\alpha)}{\mathrm{T}^{2}}\right]=\log \frac{\mathrm{AR}}{\Theta \mathrm{E}^{*}}\left[1-\frac{2 \mathrm{RT}}{\mathrm{E}^{*}}\right]-\frac{\mathrm{E}^{*}}{2.303 \mathrm{RT}} \mathrm{n}=1(2)$

Where $E^{*}, R, A$ and $\theta$ are the energy of activation, the universal gas constant, pre-exponential factor and the heating rate, respectively. The correlation coefficient, $R^{2}$, was computed using the least square method by plotting the left-hand side of equation 1 or 2 vs $1000 / T$ (Fig 5 ). The $n$ value which give the best fit $\left(R^{2} \approx 1\right)$ was chosen as the order of the parameter for the decomposition stage. From the intercept and linear slop of such stages, the $A$ and $E^{*}$ values were determined. The values of activation enthalpy $\left(\Delta \mathrm{H}^{*}\right)$, the activation entropy $\left(\Delta \mathrm{S}^{*}\right)$ and the free energy of activation $\left(\Delta \mathrm{G}^{*}\right)$ given in $($ Table 6$)$ were calculated using equation (3), (4) and (5). Where the $A, k$, and $h$ are the pre-exponential factor, Boltzmann and plank's constant. The negative values of activation entropy $\left(\Delta S^{*}\right)$ indicated that the reactions are slow and the products are more stable than reactants and the positive values of $\left(\Delta S^{*}\right)$ indicated that the activated complexes for the decomposition stage has a less ordered structure compared to the reactant, further the reaction may be described as faster than normal.
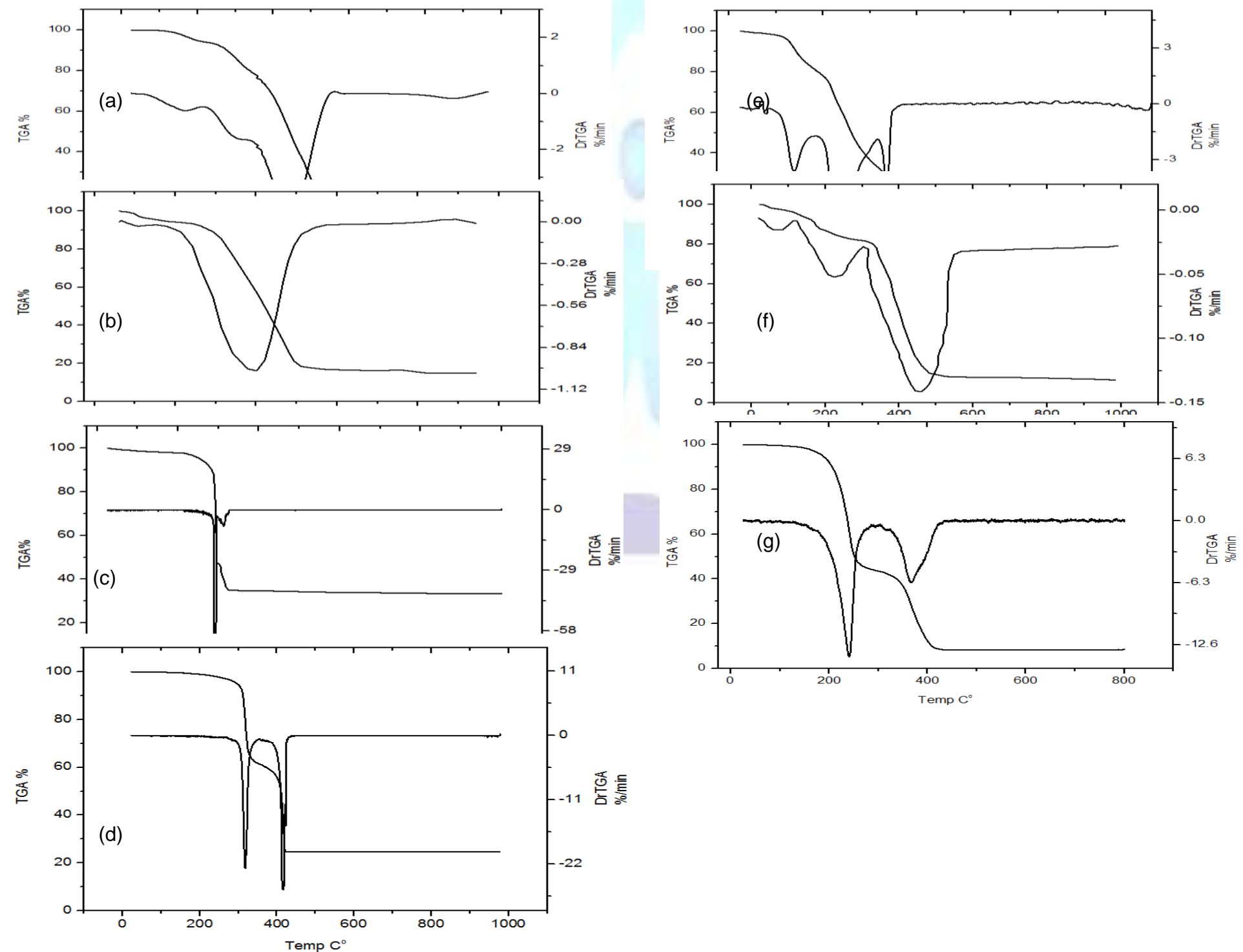
Fig 4: TGA and DrTGA curve of complexes 1, 2, 3, 4, 5, 6 and 7

The positive values of enthalpy $\left(\Delta \mathrm{H}^{*}\right)$ mean that the decomposition processes are endothermic. The values of $\left(\Delta \mathrm{G}^{*}\right)$ increase significantly for the subsequently decomposition stages, increasing the values of $\left(\Delta G^{*}\right)$ as going from one decomposition step subsequently to another reflects that the rate of removal of the subsequent ligand will be lower than that of the precedent ligand and the reactions are non-spontaneous.

$$
\begin{aligned}
& \Delta \mathrm{H}^{*}=\mathrm{E}^{*}-\mathrm{RT}(3) \\
& \Delta \mathrm{S}^{*}=2.303\left(\log \frac{\mathrm{Ah}}{\mathrm{kT}}\right) \mathrm{R}(4) \\
& \Delta \mathrm{G}^{*}=\mathrm{H}^{*}-\mathrm{TS}^{*}(5)
\end{aligned}
$$

(a)



$1000 \pi$

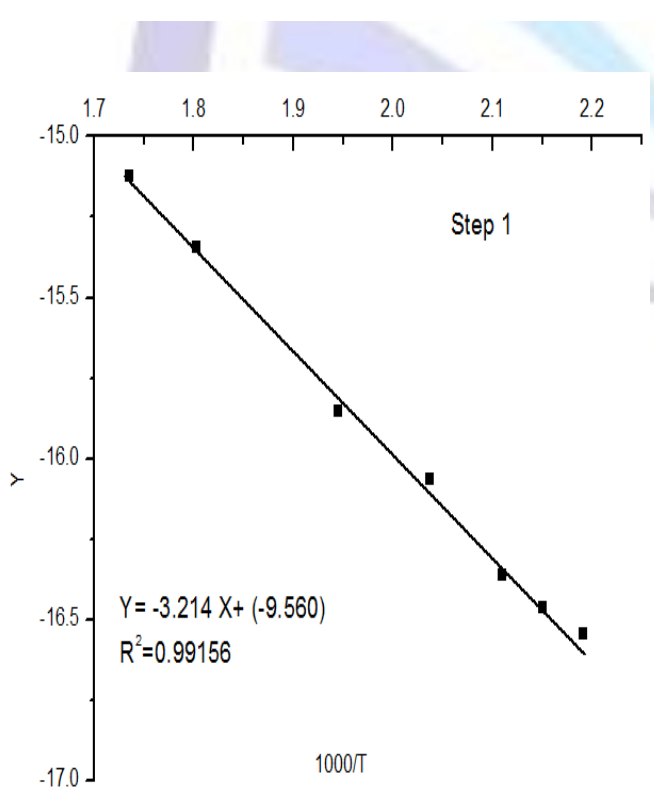

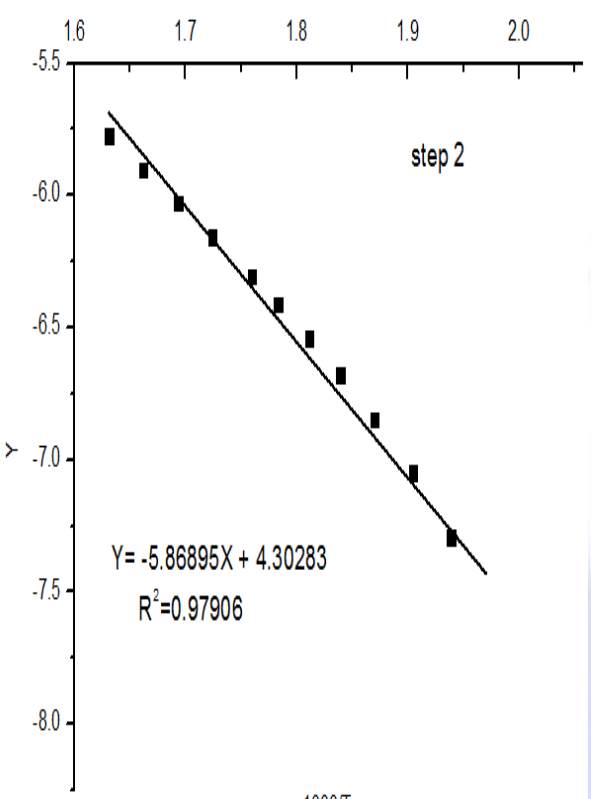

$1000 \pi$

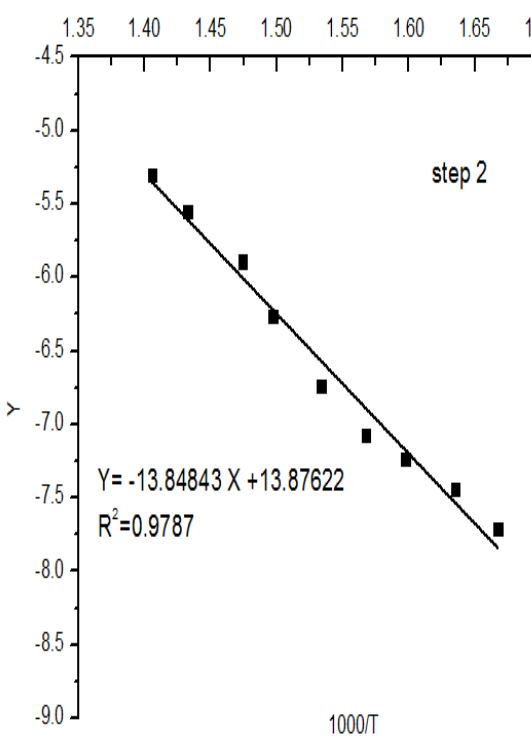


Fig 5: (a)Coats-Redfern plots for complex (1) $\left[(\mathrm{Cu})_{2}(\mathrm{ASH})_{2}\left(\mathrm{H}_{2} \mathrm{O}\right)_{2}\right]$, (b) Coats-Redfern plots for complex (3)

$[\mathrm{Ni}(\mathrm{ABH})(\mathrm{OAC})]$ where $Y=\ln \left[\left[-\ln \left[(1-\alpha) / T^{2}\right]\right.\right.$ at $n=1$, orY $=\ln \left[1-(1-\alpha)^{1-n} / \mathrm{T}^{2}(1-n)\right] n \neq 1$ and $X=1000 / T$

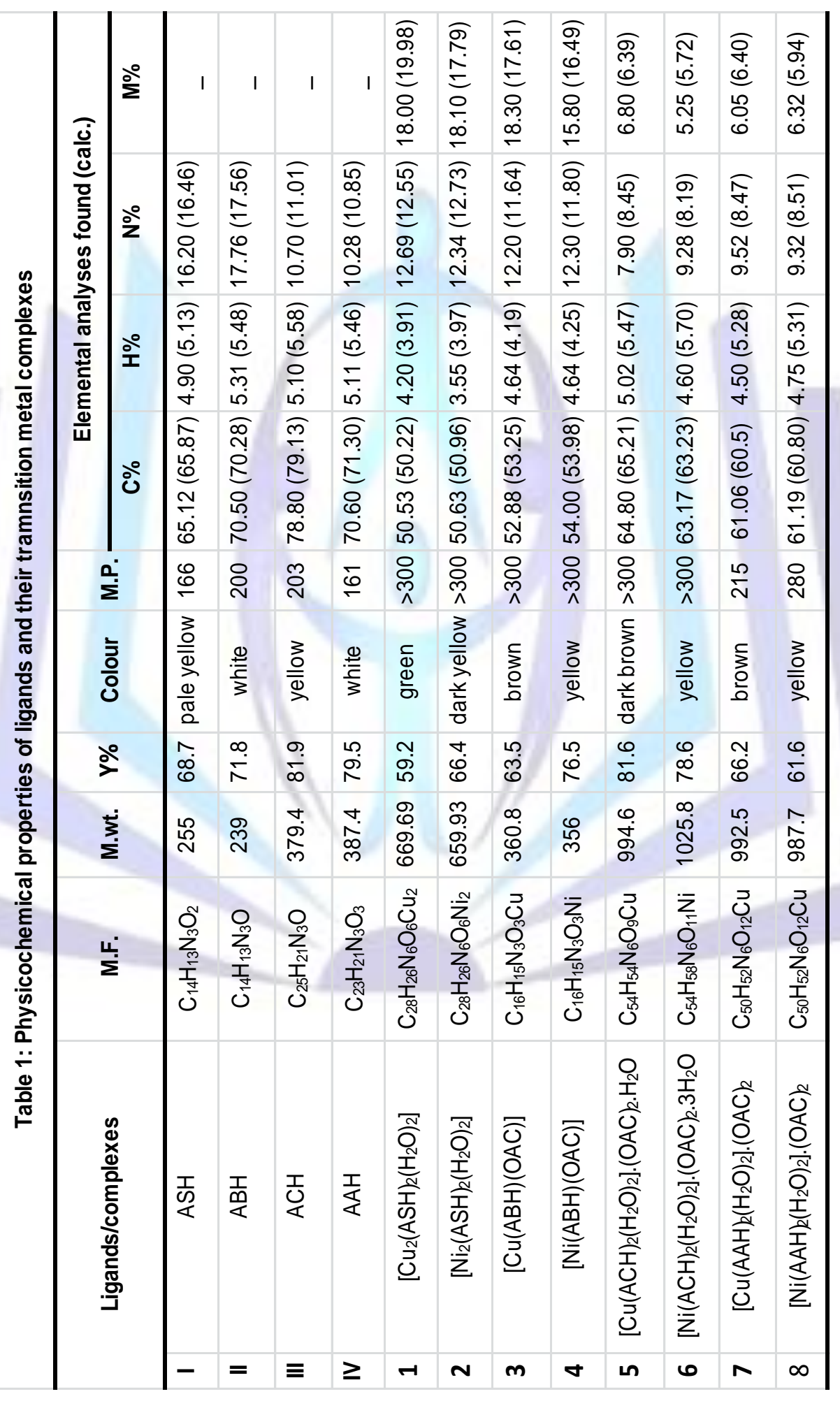




\begin{tabular}{|c|c|c|c|c|c|c|c|}
\hline 颜 & 誉拿 & \% & & & $\bar{q}$ & & 手 \\
\hline 旁 & 铱亭 & 总 & $\approx$ & $\overline{\bar{v}}$ & $\frac{\circ}{5 !}$ & & 咹 \\
\hline 颜 & 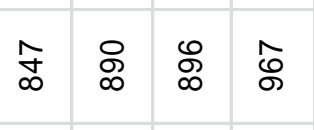 & 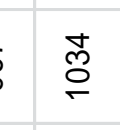 & 气 & 5 & $\%$ & &  \\
\hline $5 \frac{0}{0}$ & 黷囬 & & & & & & \\
\hline & 11 & 旺 & & & & & 黑墨 \\
\hline & 1 & 兽 & 兽 & 量 & 总 & & \\
\hline & 墨 & 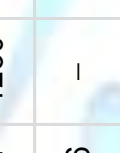 & & 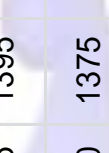 & $\stackrel{8}{2}$ & & \\
\hline & 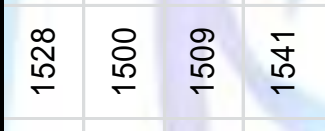 & & & 等 & & & \\
\hline & 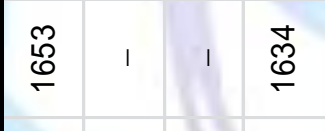 & 1 & & : & & & \\
\hline & 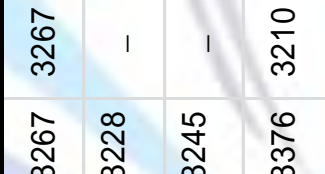 & & & 总 & हू & & \\
\hline & 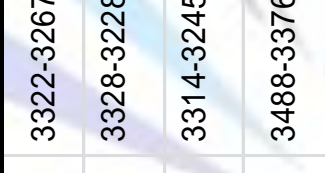 & & & & & & \\
\hline & 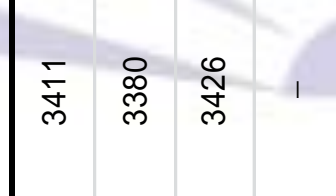 & & & & & & \\
\hline & 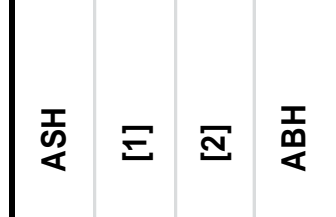 &  & & & & & \\
\hline
\end{tabular}


Table 3: ${ }^{1} H$ NMR chemical shifts ( $\delta$, ppm) of ligands

\begin{tabular}{|c|c|c|c|c|c|}
\hline Ligand & $\delta(\mathbf{C H}=\mathbf{N})$ & $\delta(\mathbf{N}-\mathbf{H})$ & $\delta(\mathbf{P h}-$ proton$)$ & $\delta\left(\mathbf{N H}_{2}\right)$ & $\delta(\mathbf{O H})$ \\
\hline ASH & $8.6(\mathrm{~s}, 1 \mathrm{H})$ & $11.4(\mathrm{~s}, 1 \mathrm{H})$ & $6.5-7.6(\mathrm{~m}, 8 \mathrm{H})$ & $6.4(\mathrm{~S}, 2 \mathrm{H})$ & $11.8(\mathrm{~S}, 1 \mathrm{H})$ \\
\hline ABH & $8.4(\mathrm{~S}, 1 \mathrm{H})$ & $11.5(\mathrm{~S}, 1 \mathrm{H})$ & $6.5-7.7(\mathrm{~m}, 9 \mathrm{H})$ & $6.3(\mathrm{~S}, 2 \mathrm{H})$ & - \\
\hline ACH & $8.7(\mathrm{~d}, 2 \mathrm{H})$ & $7.4(\mathrm{~S}, 1 \mathrm{H})$ & $6.9-7.7(\mathrm{~m}, 14 \mathrm{H})$ & - & - \\
\hline AAH & $8.7(\mathrm{~S}, 2 \mathrm{H})$ & $7.6(\mathrm{~S}, 1 \mathrm{H})$ & $6.3-7.7(\mathrm{~m}, 12 \mathrm{H})$ & - & - \\
\hline
\end{tabular}

Table 4: Electronic absorption bands, magnetic moments and molar conductivity of metal complexes

\begin{tabular}{|c|c|c|c|c|c|}
\hline Comp. No. & $\begin{array}{c}\text { d-d transition } \\
\left(\mathrm{cm}^{-1}\right)\end{array}$ & $\begin{array}{l}\text { d-d transition } \\
\text { assignment }\end{array}$ & $\begin{array}{c}\boldsymbol{\mu}_{\text {eff. }} \\
\text { (B.M.) }\end{array}$ & $\begin{array}{c}\Lambda \\
\left(\Omega^{-1} \mathrm{~cm}^{2} \mathrm{~mol}^{-1}\right)\end{array}$ & $\begin{array}{l}\text { Geometry } \\
\text { structure }\end{array}$ \\
\hline [1] & 15432 & ${ }^{2} \mathrm{E}_{g} \longrightarrow{ }^{2} \mathrm{~T}_{2 g}$ & 2.02 & 14 & square pyrmidal \\
\hline \multirow[t]{2}{*}{ [2] } & 18762 & ${ }^{3} \mathrm{~B}_{1 \mathrm{~g}} \longrightarrow{ }^{3} \mathrm{E}_{\mathrm{g}}(\mathrm{p})$ & \multirow{2}{*}{2.86} & \multirow{2}{*}{26} & \multirow{2}{*}{ square pyrmidal } \\
\hline & 24390 & ${ }^{3} \mathrm{~B}_{1 \mathrm{~g}} \longrightarrow{ }^{3} \mathrm{~A}_{2 \mathrm{~g}}(\mathrm{p})$ & & & \\
\hline [3] & 17544 & ${ }^{2} \mathrm{~T}_{2} \longrightarrow{ }^{2} \mathrm{E}$ & 1.83 & 10 & tetrahedral \\
\hline \multirow[t]{2}{*}{ [4] } & 19493 & ${ }^{3} \mathrm{~T}_{1}(\mathrm{~F}) \longrightarrow{ }^{3} \mathrm{~T}_{1}(\mathrm{P})$ & \multirow{2}{*}{3.36} & \multirow{2}{*}{29} & \multirow{2}{*}{ tetrahedral } \\
\hline & 27624 & ${ }^{3} \mathrm{~T}_{1}(\mathrm{~F}) \longrightarrow{ }^{3} \mathrm{~A}_{2}(\mathrm{~F})$ & & & \\
\hline [5] & 15873 & ${ }^{2} \mathrm{E}_{\mathrm{g}} \longrightarrow{ }^{2} \mathrm{~T}_{2 \mathrm{~g}}$ & 1.62 & 99 & octahedral \\
\hline \multirow[t]{2}{*}{ [6] } & 16234 & ${ }^{3} \mathrm{~A}_{2 \mathrm{~g}}(\mathrm{~F}) \longrightarrow{ }^{3} \mathrm{~T}_{1 \mathrm{~g}}(\mathrm{~F})$ & \multirow{2}{*}{2.8} & \multirow{2}{*}{137} & \multirow{2}{*}{ octahedral } \\
\hline & 24390 & ${ }^{3} \mathrm{~A}_{2 \mathrm{~g}}(\mathrm{~F}) \longrightarrow{ }^{3} \mathrm{~T}_{1 \mathrm{~g}}(\mathrm{P})$ & & & \\
\hline [7] & 16528 & ${ }^{2} \mathrm{E}_{\mathrm{g}} \longrightarrow{ }^{2} \mathrm{~T}_{2 \mathrm{~g}}$ & 1.71 & 145 & octahedral \\
\hline \multirow[t]{2}{*}{ [8] } & 14265 & ${ }^{3} \mathrm{~A}_{2 g}(\mathrm{~F}) \longrightarrow{ }^{3} \mathrm{~T}_{1 \mathrm{~g}}(\mathrm{~F})$ & \multirow{2}{*}{2.87} & \multirow{2}{*}{129} & \multirow{2}{*}{ octahedral } \\
\hline & 16447 & ${ }^{3} A_{2 g}(F) \longrightarrow{ }^{3} T_{1 g}(P)$ & & & \\
\hline
\end{tabular}


Table 5: Thermogravimetric analysis data of metal complexes

\begin{tabular}{|c|c|c|c|c|c|}
\hline Comp. No. & $\begin{array}{c}\text { DTG }_{\max } \\
\left(\mathbf{C}^{\circ}\right)\end{array}$ & $\begin{array}{l}\text { Temp. } \\
\text { range }\end{array}$ & eliminated species & $\begin{array}{l}\text { \%mass loss } \\
\text { found (calc.) }\end{array}$ & $\begin{array}{l}\text { Metallic residual } \\
\text { \% found (calc.) }\end{array}$ \\
\hline \multirow[t]{3}{*}{ [1] } & 167 & $99-220$ & $2 \mathrm{H}_{2} \mathrm{O}$ (coord.) & $5.89(5.37)$ & \multirow{3}{*}{$\begin{array}{c}2 \mathrm{CuO} \\
24.59(23.74)\end{array}$} \\
\hline & 320 & $220-338$ & $2 \mathrm{HCN}$ and $2 \mathrm{CN}$ & $15.10(15.80)$ & \\
\hline & 449 & $338-529$ & $\mathrm{C}_{24} \mathrm{H}_{20} \mathrm{~N}_{2} \mathrm{O}_{2}$ & $54.42(54.90)$ & \\
\hline \multirow[t]{2}{*}{ [2] } & 108 & $74-163$ & $2 \mathrm{H}_{2} \mathrm{O}$ (coord.) & $4.76(5.44)$ & \multirow{2}{*}{$\begin{array}{c}2 \mathrm{Ni} \\
17.73(17.79) \\
\end{array}$} \\
\hline & 401 & $236-571$ & the remaining of ligand & $76.56(76.76)$ & \\
\hline \multirow[t]{2}{*}{ [3] } & 290 & $211-293$ & $\mathrm{CH}_{3} \mathrm{COO}^{-}, \mathrm{N}_{2}, \mathrm{HCN}$ and $\mathrm{C}_{6} \mathrm{H}_{5}$ & $52.24(52.98)$ & \multirow{2}{*}{$\begin{array}{c}\mathrm{CuO}+4 \mathrm{C} \\
34.88(35.33)\end{array}$} \\
\hline & 313 & $292-336$ & $\mathrm{C}_{3} \mathrm{H}_{8}$ & $12.88(11.64)$ & \\
\hline \multirow[t]{2}{*}{ [4] } & 317 & $183-353$ & $\mathrm{CH}_{3} \mathrm{COO}^{-}, 2 \mathrm{C}_{2} \mathrm{H}_{2}$ and $\mathrm{CN}$ & $37.62(38.50)$ & \multirow{2}{*}{$\begin{array}{c}\mathrm{NiO}+4 \mathrm{C} \\
23.08(24.4)\end{array}$} \\
\hline & 416 & $353-449$ & $\mathrm{C}_{6} \mathrm{H}_{6}$ and $2 \mathrm{HCN}$ & $39.30(38.2)$ & \\
\hline \multirow[t]{4}{*}{ [5] } & 139 & $42-183$ & $\mathrm{H}_{2} \mathrm{O}$ (hydr.), $2 \mathrm{CH}_{3} \mathrm{COO}^{-}, \mathrm{CO}$ and $\mathrm{NH}$ & $18.10(17.99)$ & \multirow{4}{*}{$\begin{array}{c}\mathrm{CuO}+2 \mathrm{C} \\
10.65(10.41)\end{array}$} \\
\hline & 220 & $183-237$ & $2 \mathrm{H}_{2} \mathrm{O}$ (coord.), $5 \mathrm{HCN}$ and $3 \mathrm{C}_{2} \mathrm{H}_{2}$ & $25.53(25.04)$ & \\
\hline & 253 & $237-317$ & $2 \mathrm{C}_{2} \mathrm{H}_{2}, \mathrm{C}_{6} \mathrm{H}_{5}$ and $\mathrm{C}_{6} \mathrm{H}_{4}$ & $19.15(20.61)$ & \\
\hline & 336 & $317-374$ & $\mathrm{C}_{2} \mathrm{H}_{2}$ and $3 \mathrm{C}_{6} \mathrm{H}_{5}$ & $26.60(25.80)$ & \\
\hline \multirow[t]{3}{*}{ [6] } & 70 & $30-119$ & $3 \mathrm{H}_{2} \mathrm{O}$ (hydr.) & $5.73(5.26)$ & \multirow{3}{*}{$\begin{array}{c}\mathrm{NiO}+5 \mathrm{C} \\
12.89(13.13)\end{array}$} \\
\hline & 225 & $120-303$ & $2 \mathrm{H}_{2} \mathrm{O}$ (coord.) and $2 \mathrm{CH}_{3} \mathrm{COO}^{-}$ & $14.37(15.01)$ & \\
\hline & 455 & $307-594$ & the remaining of organic moiety & $67.10(66.59)$ & \\
\hline \multirow[t]{2}{*}{ [7] } & 241 & $102-295$ & $\begin{array}{c}2 \mathrm{H}_{2} \mathrm{O} \text { (coord.), } 2 \mathrm{CH}_{3} \mathrm{COO}^{-}, \mathrm{CO}, 2 \mathrm{C}_{6} \mathrm{H}_{4} \\
\text { and } 2 \mathrm{C}_{7} \mathrm{H}_{7} \mathrm{O}\end{array}$ & $55.70(55.5)$ & \multirow[t]{2}{*}{$\begin{array}{c}\mathrm{NiO}+\mathrm{C} \\
8.77(8.76)\end{array}$} \\
\hline & 368 & $295-456$ & $2 \mathrm{HCN}, 2 \mathrm{NH}$ and $\mathrm{C}_{8} \mathrm{H}_{8} \mathrm{ON}_{2}$ & $35.53(35.64)$ & \\
\hline
\end{tabular}

Table 6: Thermodynamic data of thermal decomposition of metal complexes

\begin{tabular}{|c|c|c|c|c|c|c|c|c|}
\hline $\begin{array}{c}\text { Comp. } \\
\text { no. }\end{array}$ & complex & Step & $\begin{array}{l}\mathrm{DTG}_{\max } \\
\text { (k) }\end{array}$ & $\begin{array}{c}\log A \\
\left(S^{-1}\right)\end{array}$ & $\begin{array}{c}\Delta \mathrm{E}^{*} \\
\left(\mathrm{KJ} \mathrm{mol}^{-1}\right)\end{array}$ & $\begin{array}{c}\Delta \mathrm{H}^{*} \\
\left(\mathrm{KJ} \mathrm{mol}^{-1}\right)\end{array}$ & $\begin{array}{c}\Delta \mathbf{S}^{*} \\
\left(\mathrm{KJ} \mathrm{mol}^{-1} \mathrm{~K}^{-1}\right)\end{array}$ & $\begin{array}{c}\Delta \mathbf{G}^{*} \\
\left(\mathrm{KJ} \mathrm{mol}^{-1}\right)\end{array}$ \\
\hline \multirow[t]{3}{*}{1} & \multirow[t]{3}{*}[(\mathrm{Cu})_{2}(\mathrm{ASH})_{2}(\mathrm{H}_{2}\mathrm{O})_{2}]{} & $1^{\text {st }}$ & 440.20 & 4.99 & 50.70 & 47.03 & -0.15 & 114.20 \\
\hline & & $2^{\text {nd }}$ & 593.30 & 9.43 & 112.50 & 107.50 & -0.07 & 149.10 \\
\hline & & $3^{\text {rd }}$ & 721.80 & 7.14 & 112.30 & 106.30 & -0.12 & 189.80 \\
\hline \multirow[t]{2}{*}{2} & \multirow[t]{2}{*}{$(\mathrm{Ni})_{2}($} & $1^{\text {st }}$ & 381.30 & 6.31 & 53.10 & 49.90 & -0.13 & 97.90 \\
\hline & & $2^{\text {nd }}$ & 674.40 & 1.04 & 33.40 & 27.80 & -0.23 & 184.10 \\
\hline \multirow[t]{2}{*}{3} & \multirow[t]{2}{*}[\mathrm{Cu}(\mathrm{ABH})(\mathrm{OAC})]{} & $1^{\text {st }}$ & 562.60 & 1.98 & 39.10 & 34.40 & -0.21 & 153.90 \\
\hline & & $2^{\text {nd }}$ & 586.40 & 17.70 & 201.20 & 196.30 & 0.09 & 143.90 \\
\hline \multirow[t]{2}{*}{4} & \multirow[t]{2}{*}{ [Ni(ABH)(OAC)] } & $1^{\text {st }}$ & 590.30 & 0.36 & 26.70 & 21.80 & -0.24 & 165.70 \\
\hline & & $2^{\text {nd }}$ & 689.10 & 19.40 & 265.30 & 259.60 & 0.11 & 177.50 \\
\hline \multirow[t]{4}{*}{5} & \multirow[t]{4}{*}[\mathrm{Cu}(\mathrm{ACH})_{2}(\mathrm{H}_{2}\mathrm{O})_{2}]{$\cdot(\mathrm{OAC})_{2} \cdot \mathrm{H}_{2} \mathrm{O}$} & $1^{\text {st }}$ & 411.60 & 1.74 & 27.40 & 23.99 & -0.21 & 112.20 \\
\hline & & $2^{\text {nd }}$ & 492.90 & 16.10 & 157.60 & 153.50 & 0.06 & 124.10 \\
\hline & & $3^{\text {rd }}$ & 552.70 & 13.55 & 143.80 & 139.20 & 0.01 & 134.02 \\
\hline & & $4^{\text {th }}$ & 608.90 & 35.46 & 416.70 & 411.60 & 0.43 & 151.00 \\
\hline \multirow[t]{3}{*}{6} & \multirow[t]{3}{*}[\mathrm{Ni}(\mathrm{ACH})_{2}(\mathrm{H}_{2}\mathrm{O})_{2}]{$\cdot(\mathrm{OAC})_{2} \cdot 3 \mathrm{H}_{2} \mathrm{O}$} & $1^{\text {st }}$ & 343.20 & 4.78 & 52.60 & 49.80 & -0.16 & 102.90 \\
\hline & & $2^{\text {nd }}$ & 498.10 & 4.82 & 52.90 & 48.80 & -0.16 & 126.95 \\
\hline & & $3^{\text {rd }}$ & 727.90 & 4.84 & 79.50 & 73.40 & -0.16 & 189.70 \\
\hline \multirow[t]{2}{*}{7} & \multirow[t]{2}{*}[\mathrm{Ni}(\mathrm{AAH})_{2}(\mathrm{H}_{2}\mathrm{O})_{2}]{$\cdot(\mathrm{OAC})_{2}$} & $1^{\text {st }}$ & 514.00 & 8.28 & 88.19 & 83.90 & -0.09 & 130.60 \\
\hline & & $2^{\text {nd }}$ & 641.10 & 10.20 & 137.40 & 132.10 & -0.06 & 168.33 \\
\hline
\end{tabular}




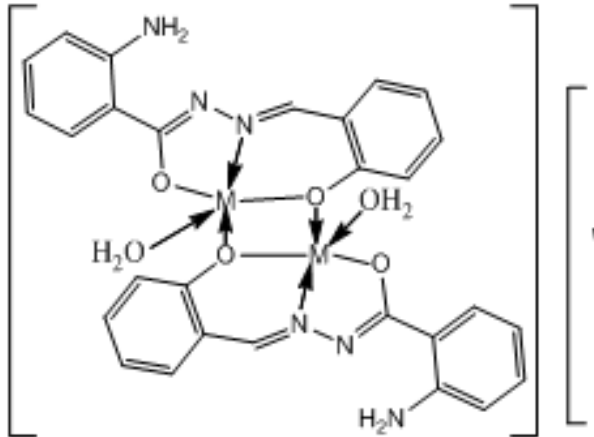

$\left[\mathrm{M}_{2}(\mathrm{ASH})_{2}\left(\mathrm{H}_{2} \mathrm{O}\right)\right]$ $\mathrm{M}=\mathrm{Cu}^{\prime \prime}, \mathrm{Ni}{ }^{\prime \prime} \mathrm{M}=\mathrm{Cu}^{\prime \prime}, \mathrm{Ni}{ }^{\prime \prime}$

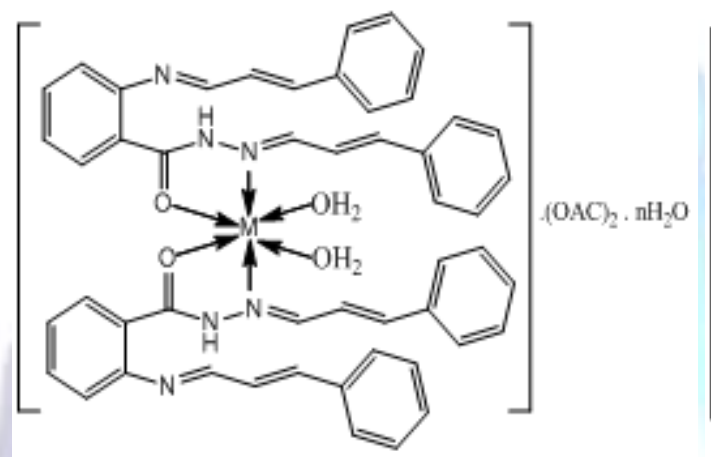

$\left[\mathrm{M}(\mathrm{ACH})_{2}\left(\mathrm{H}_{2} \mathrm{O}\right)_{2}\right] \cdot(\mathrm{OAC})_{2} \cdot \mathrm{n}\left(\mathrm{H}_{2} \mathrm{O}\right) \quad\left[\mathrm{M}(\mathrm{AAH})_{2}\left(\mathrm{H}_{2} \mathrm{O}\right)_{2}\right] \cdot(\mathrm{OAC})$

$$
\begin{aligned}
& \mathrm{M}=\mathrm{Cu}^{\prime \prime}, \mathrm{n}=1 \quad \mathrm{M}=\mathrm{Cu}^{\prime \prime}, \mathrm{Ni}^{\prime \prime} \\
& \mathrm{Ni}, \mathrm{n}=3
\end{aligned}
$$

Fig. 6: Proposed structure of metal complexes

\section{CONCLUSION}



From the elemental analysis, IR and UV-Vis spectral data, molar conductivity and magnetic measurements and thermogravimetric analyses, it can be concluded that the ligands appearin keto-form and behave as bidentate $(\mathrm{ABH}, \mathrm{ACH}$ and $\mathrm{AAH}$ ) or tridentate $(\mathrm{ASH})$ forming square pyramidal for $\mathrm{ASH}$, tetrahedral for $\mathrm{ABH}$ and octahedral geometry for $\mathrm{ACH}$ and $\mathrm{AAH}$ complexes, the thermodynamic data of decomposition processes of complexes were calculated by employing the Coats - Redfern equation.

\section{REFERENCE}

[1] "Ahmed A. El-Sherif," Inorganica Chim. Acta, vol. 362, pp. 4991-5000, 2009.

[2] "Madalina Veronica Angelusiu,Stefania-felicia Barbuceanu, Constantin Draghici, Gabriela Laura Almajan," Eur. J. Med. Chem., vol. 45, pp. 2055-2062, 2010.

[3] "K. Kashinath, Vijaykumar Durg, KalpanaBaburao and SD. Angadi," Int. J. Res. Pharm. Chem., vol. 4, pp. 557563, 2014.

[4] "Paweł Subik, Agata Białońska, Stanisław Wołowiec," Polyhedron, vol. 30, pp. 873-879, 2011.

[5] "Antonio Sousa-Pedrares, Nuria Camiña, Jaime Romero, Maria L. Durán, José A. García-Vázquez, Antonio Sousa," Polyhedron, vol. 27, pp. 3391-3397, 2008.

[6] "Mostafa El-Behery, Haifaa El-Twigry," Spectrochim. Acta - Part A Mol. Biomol. Spectrosc., vol. 66, pp. 28-36, 2007.

[7] "Yoshiya Ikawa, Toshi Nagata, Kazuhiro Maruyama," Chem. Lett., vol. 22, pp. 1049-1052, 1993.

[8] "G.M.Dongare, R.T.Parihar," J. Med. Chem. drug Discov., pp. 484-488, 2013.

[9] "Hassan, Dheefaf F," J. Al-Nahrain Univ., vol. 13, pp. 32-39, 2010.

[10] "Bharat Parashar , P. B. Punjabi , G. D. Gupta and V. K. Sharma," Int. J. ChemTech Res., vol. 1, pp. 1022-1025, 2009.

[11] "Azza A.A. Abu-Hussen, Wolfgang Linert," Spectrochim. Acta. A. Mol. Biomol. Spectrosc., vol. 74, pp. 214-223, 2009. 
[12] "Amina A.Soayed, Heba M. Refaat, Leena Sinha," J. Saudi Chem. Soc., vol. 19, pp. 217-226, 2014.

[13] "N. Kavitha, P.V. Anantha Lakshmi," J. Saudi Chem. Soc., vol. 19, pp. 575-579, 2015.

[14] "Ravindra Bhaskar, Nilesh Salunkhe, Amit Yaul, Anand Aswar," Spectrochim. ACTA Part A Mol. Biomol. Spectrosc., vol. 151, pp. 621-627, 2015.

[15] "S. R. Kelode, T. R. Kale, P. R. Mandlik," Int. J. ChemTech Res., vol. 5, pp. 362-366, 2013.

[16] "O.Sunita Devi, Ak. Manihar Singh," J. Chem. Pharm. Res., vol. 3, pp. 1055-1060, 2011.

[17] "Abeer A. Faheim, Safaa N. Abdou, Zeinab H. Abd El-Wahab," Spectrochim. Acta. A. Mol. Biomol. Spectrosc., vol. 105, pp. 109-124, 2013.

[18] "Yasmi Reyes-Ortega, José Luis Alcántara-Flores, María del Carmen Hernández-Galindo, René Gutiérrez-Pérez, Daniel Ramírez-Rosales, Sylvain Bernès, Blanca Martha Cabrera-Vivas, Alejandro Durán-Hernández, Rafael Zamorano-Ulloa," R J. Mol. Struct, vol. 788, pp. 145-151, 2006.

[19] “Ferman A. Charvez, Marilyn M. Olmstead, Pradip K. Masharak," Inorg. Chem., vol. 35, pp. 1410-1412, 1996.

[20] "Gyungse Park, Junlng Shao, Frances H. IU, Robin D. Rogers, N. Dennis Chasteen, Martin W. Brechiel, Roy P. Planalp," Inorg. Chem., vol. 40, pp. 4167-4175, 2001.

[21] “Nevin Turan, Bayram Gündüz, Hanifi Körkoca, Ragıp Adigüzel, Naki Çolak, Kenan Buldurun,” j.Mex. Chem. Soc., vol. 58, pp. 65-75, 2014.

[22] "Samir S. Kandil, Gad B. El-Hefnawy, Eman A. Baker," Thermochim. Acta, vol. 414, pp. 105-113, 2004.

[23] "Nagham S. Buttrus," Res. J. Chem. Sci., vol. 4, pp. 41-47, 2014.

[24] "Buttrus H. Nabeel, Saeed T. Farah," Res. J. Chem. Sci., vol. 2, no. 6, pp. 43-49, 2012.

[25] “A. B. P. Lever," Inorg. Electron. Spectrosc. 2nd Ed., Elsevier, Amsterdam, 1985.

[26] “A.S. El-Tabl, W. Plass, A. Buchholz, M.M. Shakdofa," J. Chem. Res., vol. 2009, pp. 582-587, 2009.

[27] "Halime Güzin Aslan, Servet Özcan, Nurcan Karacan," Inorg. Chem. Commun., vol. 14, pp. 1550-1553, 2011.

[28] "A.W. Coats, J. P. Redfern," Nature, vol. 201, p. 68, 1964. 